\title{
Rancangan Game Balinese Fruit Shooter Berbasis Virtual Reality Sebagai Media Pembelajaran
}

\author{
Made Aditya Pranata ${ }^{1}$, Gede Saindra Santyadiputra ${ }^{2}$, I Gede Partha Sindu ${ }^{3}$ \\ 1,2,3 Pendidikan Teknik Informatika, Universitas Pendidikan Ganesha, \\ Singaraja, Indonesia \\ e-mail: adityapranata50@gmail.com¹,gsaindras@undiksha.ac.id², \\ partha.sindu@undiksha.ac.id ${ }^{3}$
}

\begin{abstract}
Abstrak
Tujuan dari penelitian ini adalah untuk memperkenalkan buah lokal Bali kepada generasi muda khususnya anak-anak TK melalui game dan membantu proses pembelajaran di TK (Taman Kanak Kanak) dengan sub tema buah-buahan. Pengembangan aplikasi ini ditunjukkan kepada anak-anak TK agar dapat memotivasi minat belajar, menambah wawasan terkait dengan buah lokal Bali, memperkenalkan buah lokal Bali kepada anak-anak TK, serta memberikan gambaran bentuk dari buah lokal Bali.

Rancangan game Balinese Fruit Shooter berbasis Virtual Reality sebagai media pembelajaran menggunakan model $A D D I E$ yang terdiri dari lima langkah, yaitu Analisis (Analyze), Desain (Design), Pengembangan (Development), Implementasi (Implementation), Evaluasi (Evaluation). Pada model ini memberikan kesempatan untuk melakukan evaluasi dan revisi secara terus menerus dalam setiap fase yang dilalui, sehingga produk yang dihasilkan menjadi produk yang valid.

Hasil akhir dari penelitian ini berupa aplikasi game Balinese Fruit Shooter berbasis Virtual Reality tentang game menembak buah lokal Bali berdasarkan warna sebagai pengenalan buah lokal Bali untuk anak usia dini yang dapat dimainkan melalui komputer dengan alat HTC VIVE. Berdasarkan hasil yang diperoleh dapat disimpulkan bahwa game Balinese Fruit Shooter, dapat digunakan untuk pembelajaran dengan sub tema buah-buahan.
\end{abstract}

Kata Kunci - Virtual Reality, HTC VIVE, 3D, game

\begin{abstract}
The purpose of this research is to introduce the local fruits of Bali to the young generation, especially kindergarten children through games and help the learning process in Kindergarten with the sub theme of fruits. The development of this application is shown to kindergarten children in order to motivate the learning interest, add insights related to local fruit of Bali, introduce local fruit of Bali to kindergarten children, and provide an overview of the shape local fruit of Bali.

Design of Balinese Fruit Shooter game based on Virtual Reality as instructional media using ADDIE model consisting of five steps, namely Analysis, Design, Development, Implementation, Evaluation. This model provides an opportunity to conduct continuous evaluation and revision in every phase traversed, so that the resulting product becomes a valid product.

The end result of this research is the application of Balinese Fruit Shooter game based on Virtual Reality about Balinese Fruit Shooter game based on the color of Bali as the introduction local fruit of Bali for early childhood that can be played through computer with HTC VIVE tool. Based on the results obtained can be concluded that the game Balinese Fruit Shooter, can be used for learning with sub themes of fruits.
\end{abstract}

Keywords - Virtual Reality, HTC VIVE, 3D, games 


\section{PENDAHULUAN}

Kekayaan keanekaragaman jenis buahbuahan asli Bali yang melimpah sampai sekarang belum dimanfaatkan secara optimal, bahkan ada kecendrungan keberadaanya semakin terdesak oleh banyaknya buah-buahan import yang beredar di daerah Bali. Fenomena yang terjadi saat ini adalah adanya peredaran buah-buahan impor kian menjamur di pasar dalam negeri karena para distributor dan pedagang eceran lebih tertarik menjualnya [2]. Disamping itu, adanya perubahan iklim, intensitas serangan hama dan penyakit, pembukaan hutan, perubahan perilaku masyarakat yang cenderung berorientasi komersial dan berlakunya perdagangan bebas, menyebabkan kelestarian keragaman buah-buahan lokal makin mengkhawatirkan. Beberapa jenis buah yang dulu sangat populer di masyarakat, saat ini sudah mulai jarang ditemukan. Generasi sekarang lebih mengenal berbagai buah impor daripada buah lokal khususnya di Bali [1]. Oleh karena itu diperlukan adanya media yang digunakan untuk memperkenalkan buah lokal Bali, salah satunya adalah media pemebelajaran untuk TK.

Pendidik sudah mulai mendapatkan akses untuk menggunakan berbagai macam teknologi guna meningkatkan efektifitas dalam proses belajar dan pembelajaran. Dari Taman Kanak atau TK juga mulai menggunakan teknologi dalam proses pembelajarannya dalam bentuk sebuah media pembelajaran. Media pembelajaran yang digunakan dalam pembelajaran TK mengacu terhadap kesesuaian media dengan tema yang diajarkan dan media pembelajaran yang digunakan dianggap dapat menyampaikan materi yang akan disampaikan, sehingga tujuan pembelajaran dapat dicapai.

Berdasarkan pemaparan tersebut, kekayaan sumber daya hayati yang melimpah ini khususnya di Bali perlu disosialisasikan kepada generasi muda salah satunya adalah melalu media pembelajaran. Sehingga akan dikembangkan sebuah game virtual reality yang menampilkan lingkungan 3D tentang game 3D shooter disimulasikan dalam komputer dengan alat HTC VIVE.

\section{LANDASAN TEORI}

\section{A. Media Pembelajaran}

Media merupakan segala sesuatu yang dapat menyalurkan informasi dari sumber informasi kepada penerima informasi. Proses belajar mengajar pada dasarnya merupakan proses komunikasi, sehingga media yang digunakan dalam pembelajaran disebut media pembelajaran. Media pembelajaran adalah alat bantu dalam proses belajar mengajar dan sesuatu apa pun yang dapat dipergunakan untuk merangsang pikiran, perhatian, perasaan, dan kemampuan atau ketrampilan pebelajar tersebut sehingga dapat mendorong terjadinya proses belajar atau kegiatan pembelajaran [3].

\section{B. Buah Lokal Bali}

Pengertian buah lokal berdasarkan Peraturan Daerah Provinsi Bali Nomor 3 Tahun 2013 tentang Perlindungan Buah Lokal adalah semua jenis buah-buahan yang dikembangkan dan dibudidayakan di Bali, sedangkan produk buah lokal adalah semua hasil dan turunan hasil yang berasal dari tanaman buah lokal yang masih segar atau yang telah diolah. Adapun buah-buahan yang digunakan dalam game Balinese Fruit Shooter, yaitu buah bidara, cermai, gowok, kawista, anggur, duku, buni, jamblang, durian, jambu air, jambu biji, manga, manggis, nangka, rambutan, srikaya, dan stroberi

\section{Game}


Game dapat diartikan sebgai sebuah kegiatan yang bersifat menghibur dimana terdapat peraturan dalam game tersebut. Permainan dalam hal ini merujuk pada pengertian kelincahan intelektual (Intellectual Playability Game) yang juga bisa diartikan sebagai arena keputusan dan aksi pemainnya [6]. Peraturan pada game bertujuan untuk membatasi perilaku permainan sehingga mencapai tujuan game tersebut. Tentunya game memiliki berbagai manfaat dalam kehidupan, salahsatunya adalah meningkatkan keterampilan terkait dengan game yang dimainkannya. Ada berbagai jenis genre dari game, salah satunya adalah game FPS. Genre ini menggunakan Sudut pandangnya orang pertama, yaitu pemain itu sendiri secara langsung dan pemain tidak menjalankan tokoh.

\section{Virtual Reality}

Virtual reality adalah sebuah teknologi yang membuat pengguna atau user dapat berinteraksi dengan lingkungan yang ada dalam dunia maya yang disimulasikan oleh komputer, sehingga pengguna merasa berada di dalam lingkungan tersebut [4]. Virtual reality sangat membantu dalam mensimulasikan sesuatu yang sulit untuk dihadirkan secara langsung dalam dunia nyata. Kelebihan utama dari virtual reality adalah pengalaman yang membuat user merasakan sensasi dunia nyata dalam dunia maya.

\section{E. HTC VIVE}

HTC VIVE merupakan alat yang digunakan untuk menunjang teknologi virtual reality yang dibuat oleh HTC dan Valve Corporation. Dalam situs resmi HTC VIVE mengatakan bahwa HTC VIVE dapat digunakan untuk melihat dan bergerak disekitar lokasi pisikal dalam lingkungan virtual dan dikarenakan lokas fisikal telah dilacak, maka pengguna dapat mengeksplorasi dan berinteraksi dengan lingkungan virtual. Alat ini terdiri dari headset, controllers, dan base stations yang diperlukan untuk menghubungkan dengan lingkungan virtual.
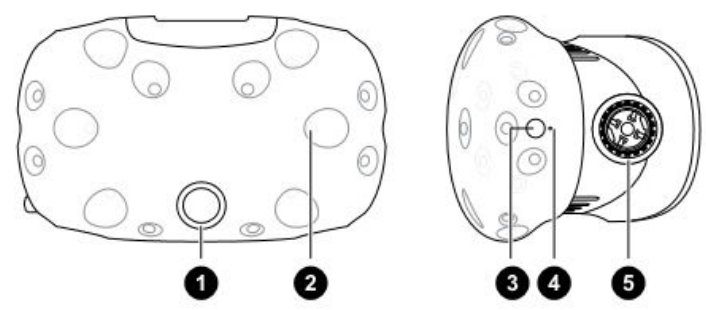

Gambar 1. Komponen headset HTC VIVE (Sumber: VIVE, 2016)

\section{F. Unity}

Unity 3D merupakan sebuah aplikasi yang terintegrasi untuk membuat bentuk objek tiga dimensi (3D) pada video games atau untuk konteks interaktif lain seperti Visualisasi Arsitektur atau animasi 3D real-time dengan lingkungan pengembangan Unity $3 D$ berjalan pada Microsoft Windows dan Mac Os $X$, serta aplikasi yang dibuat dengan Unity $3 D$ dapat berjalan pada Windows, Mac, Xbox 360, Playstation 3, Wii, iPad, iPhone dan tidak ketinggalan pada platform Android [5].

\section{G. Blender}

Blender merupakan perangkat lunak yang bersifat open source digunakan untuk membuat animasi tiga dimensi. Selain itu, perangkat lunak ini juga dapat digunakan untuk membuat animasi, evek visual, model cetak 3D, aplikasi 3D interaktif dan pendukung dalam pembuatan game 3D. Blender memiliki beberapa fitur termasuk rigging, animation, simulation, rendering, compositing and motion tracking, even video editing and game creation.

\section{METODOLOGI}




\section{A. Jenis Penelitian}

Penelitian ini merupakan jenis Penelitian Pengembangan atau Research and Development $(R \& D$ ) yakni metode penelitian yang digunakan untuk menghasilkan produk tertentu, dan menguji kefektifan produk tersebut.

\section{B. Model Pengembangan}

Pengembangan game "Balinese Fruit Shooter" berbasis virtual reality menggunakan model ADDIE atau Analysis, Design, Development, Implementation dan Evaluation. Namun, pada artikel ini akan dibahas pada bagian rancangan, yaitu Analysis, Design dan Evaluation.

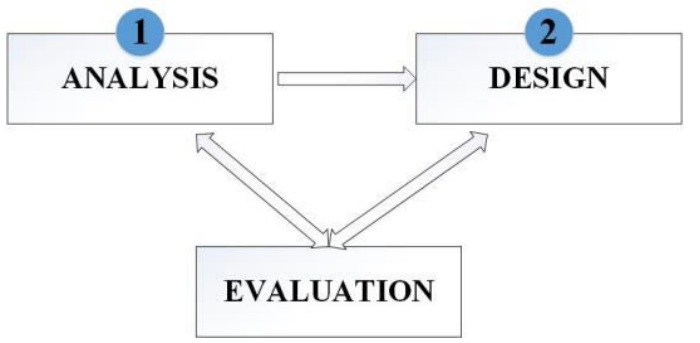

Gambar 2. Tahap model ADDIE

\section{a) Analysis}

Tahap pertama model ADDIE adalah analisis mengetani tentang pengumpulan informasi dan kebutuhan secara lengkap kemudian dianalisis dan didefinisikan kebutuhan yang harus dipenuhi oleh aplikasi yang akan dibangun.

\section{Analisis Masalah dan Solusi}

- Buah lokal Bali ada kecendrungan keberadaanya semakin terdesak oleh banyaknya buah-buahan import yang beredar di berbagai kota Indonesia

- Adanya perubahan iklim, intensitas serangan hama dan penyakit, pembukaan hutan, perubahan perilaku masyarakat yang cenderung berorientasi komersial dan berlakunya perdagangan bebas menyebabkan kelestarian keragaman buah-buahan lokal makin mengkhawatirkan

- Beberapa jenis buah yang dulu sangat populer di masyarakat, saat ini sudah mulai jarang ditemukan. Generasi sekarang lebih mengenal berbagai buah impor daripada buah lokal atau buah nusantara

2. Kebutuhan Fungsional

- Aplikasi mampu menampilkan main menu (menu utama) sebelum menuju ke permainan. Adapun adapun bagian dari main menu, yaitu Mulai, Tentang, Pengaturan, Skor Tertinggi dan Keluar.

- Aplikasi mampu menampilkan pilihan tempat bermain, yaitu ruang bermain, halaman sekolah, dan hutan.

- Aplikasi mampu memulai permainan baru dan menampilkan game utama, yaitu menembak buah lokal Bali.

- Aplikasi mampu menampilkan poin tertinggi pada permainan.

- Apliaksi mampu menampilkan skor yang telah didapat dari hasil menembak buah lokal Bali.

- Apliasi mampu mengeluarkan suara nama buah lokal Bali yang telah ditembak oleh pemain.

- Aplikasi mampu mengatur volume suara dari apliaksi.

- Aplikasi mampu menampilkan informasi tentang game dan identitas pengembang.

- Aplikasi mampu menampilkan cara bermain (tutorial)

- Aplikasi mampu menampilkan perintah keluar dari aplikasi

3. Kebutuhan Non Fungsional

- Aplikasi dapat digunakan secara interaktif, dan tidak berbelit-belit dan dengan menu-menu / pilihan yang sudah ditetapkan oleh peneliti.

- Aplikasi Game Balinese Fruit Shooter ini berjalan di platform windows dengan bantuan alat HTC VIVE untuk menjalankannya. 
4. Tujuan Pengembangan Perangkat Lunak

- Menampilkan main menu (menu utama) sebelum menuju ke permainan. Adapun adapun bagian dari main menu, yaitu Mulai, Cara Bermain, Pengaturan, Tentang, dan Keluar.

- Menampilkan pilihan tempat bermain, yaitu ruang bermain, halaman sekolah, dan hutan.

- Memulai permainan baru dan menampilkan game utama, yaitu menembak buah lokal Bali.

- Menampilkan poin tertinggi pada permainan
- Menampilkan skor yang telah didapat dari hasil menembak buah lokal Bali.

- Mengeluarkan suara nama buah lokal Bali yang telah ditembak oleh pemain.

- Mengatur volume suara dari apliaksi.

- Menampilkan informasi tentang game dan identitas pengembang.

- Menampilkan cara bermain (tutorial)

- Menampilkan perintah keluar dari aplikasi

b) Design

1. Use Case Diagram

Berikut adalah use case diagram dari game Balinese Fruit Shooter berbasis virtual reality.

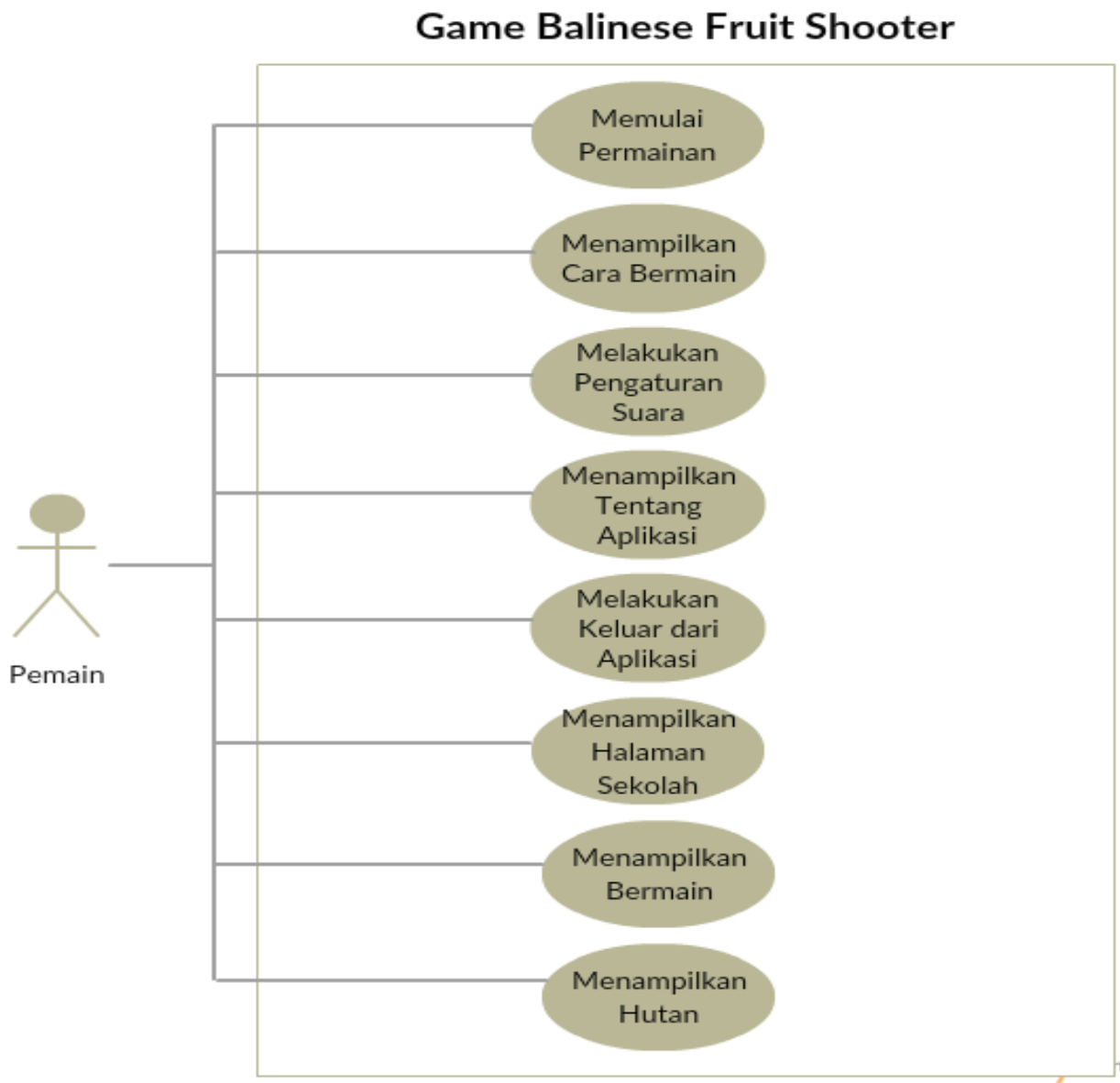

Gambar 3. Use case diagram game Balinese Fruit Shooter

2. Rancangan Struktur Navigasi

Rancangan struktur navigasi game

Balinese fruit shooter berbasis virtual reality sebagai media pembelajaran dapat dilihat pada Gambar 4. 


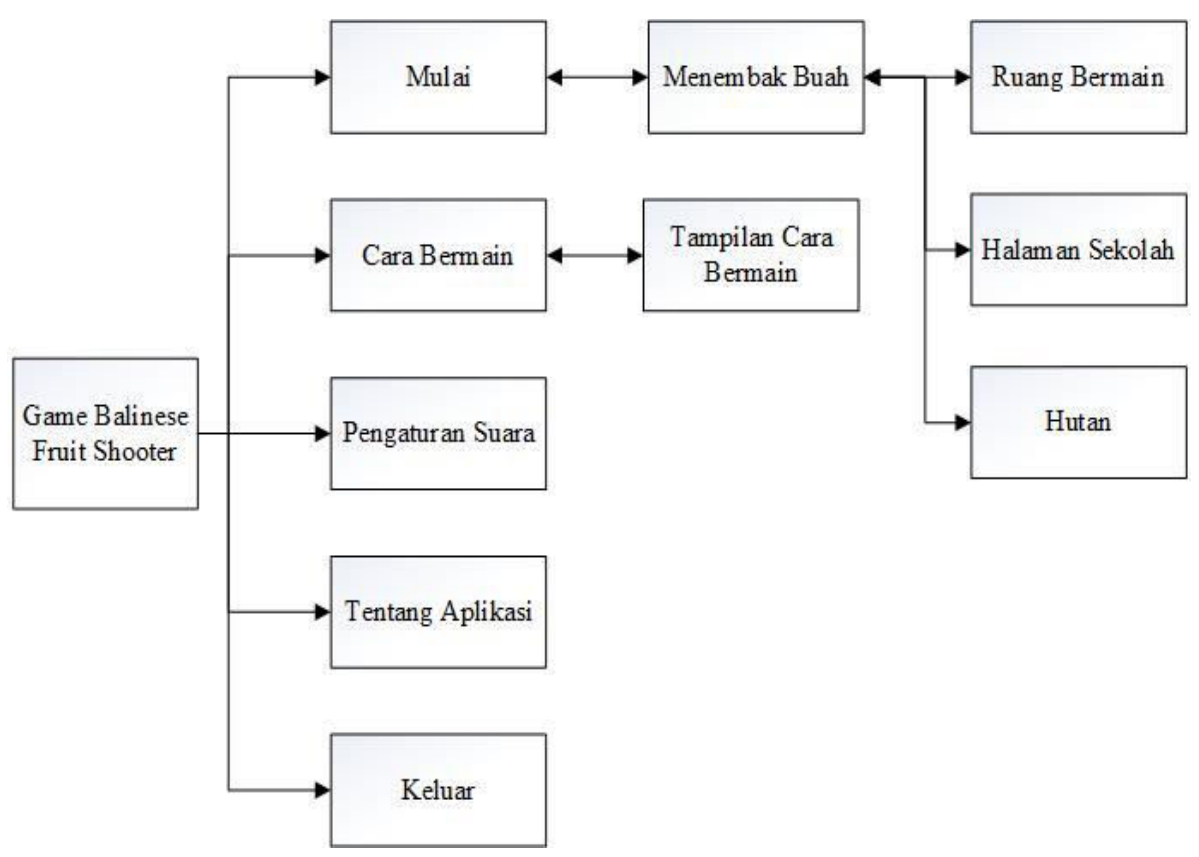

Gambar 4. Rancangan struktur navigasi Balinese Fruit Shooter berbasis

3. Rancangan Antarmuka Perangkat Lunak

- Rancangan Antarmuka Tampilan Awal Lingkungan (kelas)

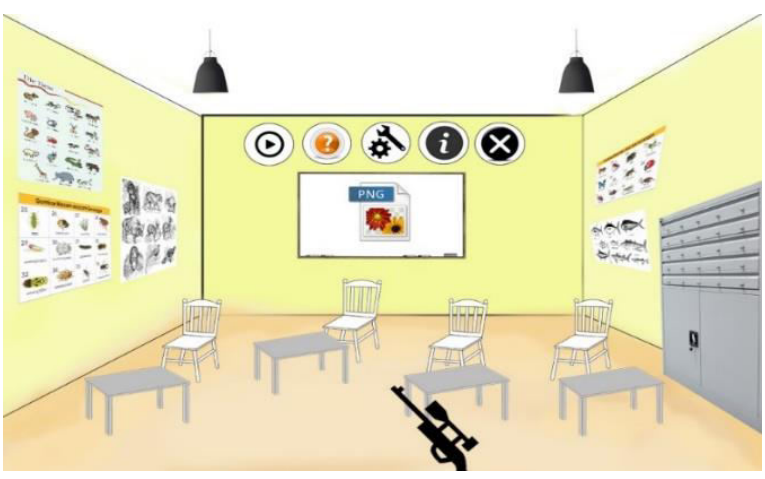

Gambar 5. Rancangan Antarmuka Tampilan Awal Lingkungan (kelas)

Pada bagian tampilan awal game, terdapat lima button, yaitu mulai, cara bermain, pengaturan, tentang dan keluar. Untuk memulai, dengan cara menembak button mulai tersebut, begitu juga pada button keluar dan button lainnya.
- Rancangan Antarmuka Tampilan Mulai

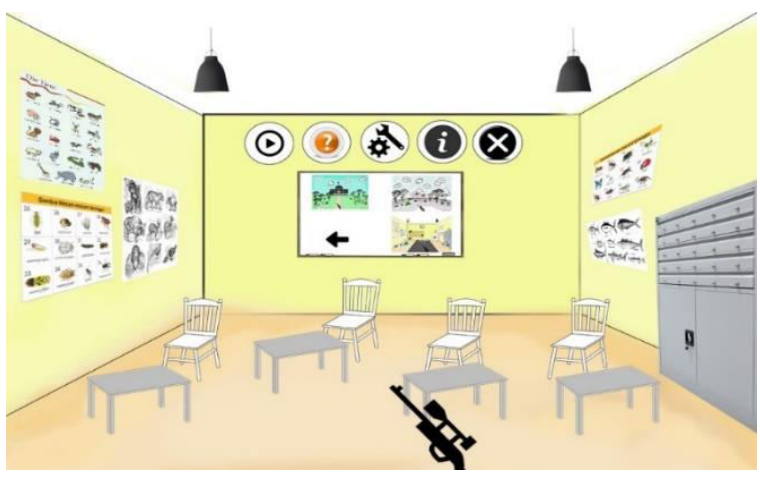

Gambar 6. Rancangan Antarmuka

Tampilan Mulai

Pada bagian tampilan mulai game, akan ditampilkan 3 lokasi bermain yang berbeda, yaitu ruang bermain, halaman sekolah dan hutan. Setiap lokasi, pemain memiliki tugas yang sama yaitu mengelompokkan buah lokal Bali berdasarkan warna dengan cara menembak. 
- Rancangan Antarmuka Tampilan Ruang Bermain

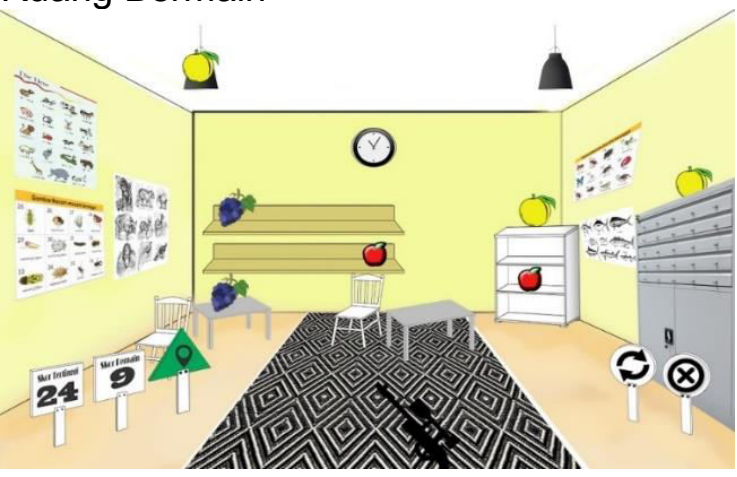

Gambar 7. Rancangan Antarmuka Tampilan Ruang Bermain

Pada bagian ini, terdapat 2 button yaitu keluar dan ulang dan 2 hud yaitu skor game dan skor tertinggi. Pemain diharapkan menembak buah lokal Bali sebanyak-banyaknya untuk mencapai skor tertinggi sesuai dengan indikator warna yang sudah tersedia.

- Rancangan Antarmuka Tampilan Halaman Sekolah

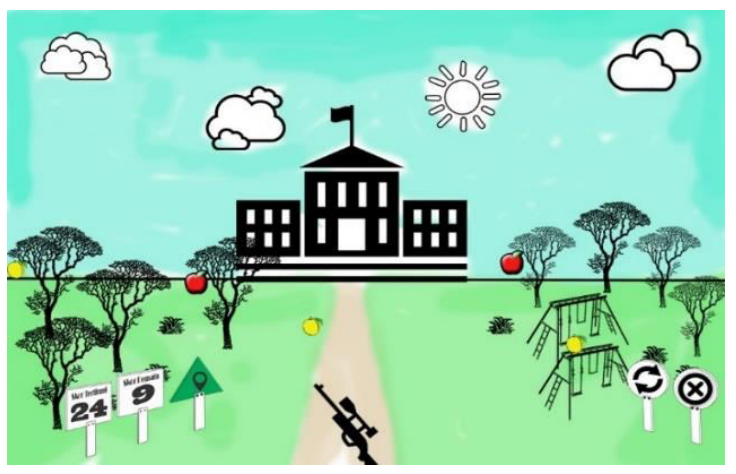

Gambar 8. Rancangan Antarmuka Tampilan Halaman Sekolah

Pada bagian ini, terdapat 2 button yaitu keluar dan ulang dan 2 hud yaitu skor game dan skor tertinggi. Pemain diharapkan menembak buah lokal Bali sebanyak-banyaknya untuk mencapai skor tertinggi sesuai dengan indikator warna yang sudah tersedia.
- Rancangan Antarmuka Tampilan Hutan

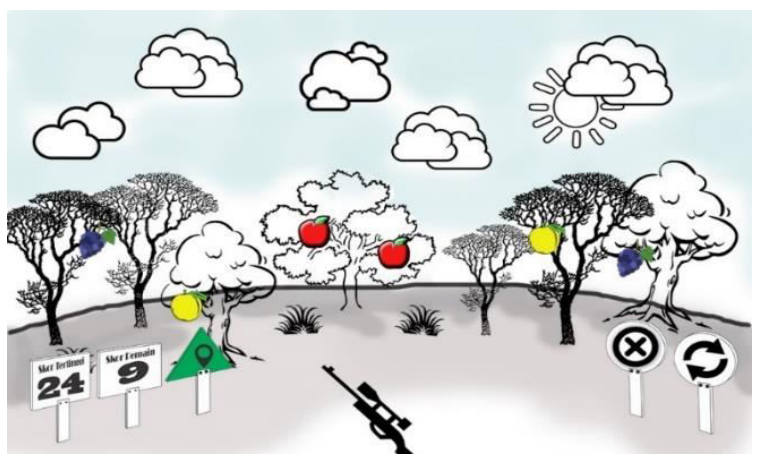

Gambar 9. Rancangan Antarmuka

Tampilan Hutan

Pada bagian ini, terdapat 2 button yaitu keluar dan ulang dan 2 hud yaitu skor game dan skor tertinggi. Pemain diharapkan menembak buah lokal Bali sebanyak-banyaknya untuk mencapai skor tertinggi sesuai dengan indikator warna yang sudah tersedia.

- Rancangan Antarmuka Tampilan Cara Bermain

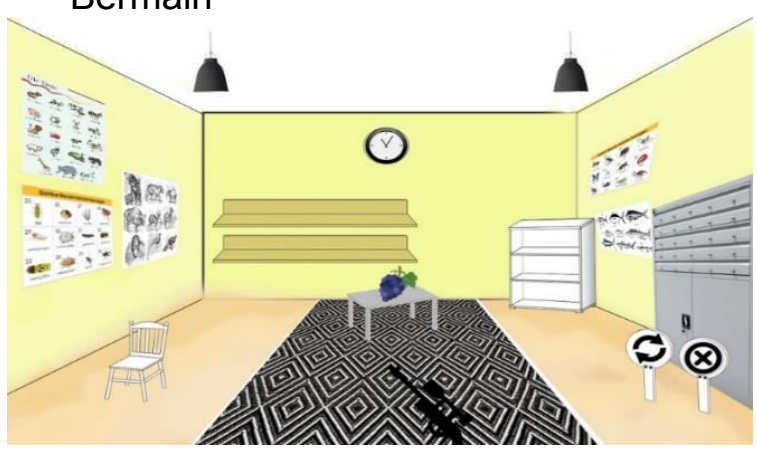

Gambar 10. Rancangan Antarmuka Tampilan Cara Bermain

Pada tampilan ini akan dijelaskan cara bermain melalui suara dan pemain akan dapat mencoba apa yang diinstruksikan.

4. Instrumen Pengujian 
Tabel 1. Kisi-Kisi Instrumen Angket Pengujian Kebenaran Proses

\begin{tabular}{|c|c|c|}
\hline \multirow[t]{2}{*}{ No } & \multicolumn{2}{|l|}{ Butir Penilaian } \\
\hline & Positif & Negatif \\
\hline \multirow{5}{*}{1} & \multicolumn{2}{|l|}{ Main Menu State } \\
\hline & $\begin{array}{l}\text { Saat aplikasi dibuka maka, akan muncul antarmuka Menu Utama yang } \\
\text { mempunyai } 5 \text { button yaitu Mulai, Cara Bermain, Tentang Aplikasi, } \\
\text { Pengaturan Suara dan Keluar. }\end{array}$ & \\
\hline & Pada antarmuka Tentang akan ditampilkan informasi mengenai sistem. & \\
\hline & $\begin{array}{l}\text { Ketika button Keluar pada antarmuka pada tampilan awal lingkungan/ } \\
\text { menu utama ditembak maka aplikasi akan keluar. }\end{array}$ & \\
\hline & $\begin{array}{l}\text { Saat menuju ke button yang diinginkan, aplikasi merespon sesuai degan } \\
\text { button yang dipilih }\end{array}$ & \\
\hline \multirow[t]{9}{*}{2} & \multicolumn{2}{|l|}{ Game State } \\
\hline & $\begin{array}{l}\text { Pada antarmuka Mulai akan menuju ke tampilan pemilihan tempat } \\
\text { bermain }\end{array}$ & \\
\hline & Ketika trigger pada controller di-press, maka senjata akan menembak. & \\
\hline & $\begin{array}{l}\text { Ketika peluru yang dikeluarkan oleh senjata mengenai buah lokal Bali } \\
\text { sesuai warna indikator, maka buah akan menghilang, mengeluarkan } \\
\text { suara nama buah yang dikenai dan menambahkan poin } 2 \text {. }\end{array}$ & \\
\hline & $\begin{array}{l}\text { Ketika peluru yang dikeluarkan oleh senjata mengenai buah tidak sesuai } \\
\text { dengan warna indikator, maka nyawa akan berkurang } 1\end{array}$ & \\
\hline & $\begin{array}{l}\text { Buah akan muncul secara recycle pada tempatnya setelah } 8 \text { hitungan. } \\
\text { Setiap hitungan memiliki waktu } 2 \text { detik. }\end{array}$ & \\
\hline & Ketika peluru mengenai button ulangi, maka game akan diulangi. & \\
\hline & $\begin{array}{l}\text { Ketika peluru mengenai button keluar, maka akan menuju ke tampilan } \\
\text { menu utama }\end{array}$ & \\
\hline & $\begin{array}{l}\text { Setelah nyawa habis, sebelum menuju ke menu utama ketika ingin } \\
\text { keluar dari game, skor yang didapat akan ditampilkan }\end{array}$ & \\
\hline \multirow[t]{4}{*}{3} & \multicolumn{2}{|l|}{ Tutorial } \\
\hline & $\begin{array}{l}\text { Saat menuju ke Cara Bermain, maka akan menuju ke tampilan ruang } \\
\text { kelas }\end{array}$ & \\
\hline & Penyampaian cara bermain dengan menggunakan suara & \\
\hline & Pemain dapat mempraktikkan apa yang diperintahkan oleh aplikasi & \\
\hline \multirow[t]{3}{*}{4} & \multicolumn{2}{|l|}{ Setting } \\
\hline & $\begin{array}{l}\text { Pada antarmuka Pengaturan Suara akan ditampilkan pengaturan suara } \\
\text { dari aplikasi. }\end{array}$ & \\
\hline & $\begin{array}{l}\text { Suara dapat diatur dengan cara menembak volume suara yang } \\
\text { diinginkan. }\end{array}$ & \\
\hline
\end{tabular}

Tabel 2. Kisi-Kisi Instrumen Angket Pengujian Kelayakan Aplikasi Sebagai Game Edukasi Pengenalan Buah Lokal Bali.

\begin{tabular}{|c|l|l|}
\hline \multirow{2}{*}{ No } & \multicolumn{2}{|c|}{ Butir Penilaian } \\
\cline { 2 - 3 } & \multicolumn{1}{|c|}{ Experience } \\
\hline 1 & \multicolumn{1}{|c|}{$\begin{array}{c}\text { Negatif } \\
\text { Shooter ini menarik dan menantang }\end{array}$} \\
\cline { 2 - 3 } & \multicolumn{1}{|c|}{$\begin{array}{l}\text { Game ini kurang memberikan } \\
\text { pengalaman yang bagus }\end{array}$} \\
\hline 2 & \multicolumn{1}{|c|}{ Goal Education } \\
\hline & Saya dapat mengetahui warna dari buah & \\
\hline
\end{tabular}




\begin{tabular}{|l|l|l|}
\hline & lokal Bali & \\
\hline & $\begin{array}{l}\text { Saya menjadi tahu tentang nama-nama dari } \\
\text { buah lokal Bali } \\
\text { dari buah lokal Bali }\end{array}$ & \\
\hline 3 & $\begin{array}{l}\text { Aplikasi ini dapat membantu } \\
\text { memperkenalkan buah lokal Bali kepada } \\
\text { anak usia dini }\end{array}$ & \\
\hline $\begin{array}{l}\text { Aplikasi ini bermanfaat sebagai wadah atau } \\
\text { media untuk mengenalkan buah-buahan } \\
\text { yang ada di Bali. }\end{array}$ & \\
\hline $\begin{array}{l}\text { Aplikasi ini mengajarkan generasi muda } \\
\text { untuk mengetahui buah-buahan lokal Bali. }\end{array}$ & \\
\hline
\end{tabular}

\begin{tabular}{|c|c|c|}
\hline \multirow[t]{2}{*}{ No } & \multicolumn{2}{|c|}{ Butir Penilaian } \\
\hline & Positif & Negatif \\
\hline \multirow[t]{3}{*}{1} & \multicolumn{2}{|c|}{$\begin{array}{c}\text { Visual Design } \\
\end{array}$} \\
\hline & $\begin{array}{l}\text { Penggunaan warna terhadap lingkungukan } \\
\text { (background) sudah sesuai }\end{array}$ & \\
\hline & Tampilan aplikasi menarik & \\
\hline \multirow[t]{5}{*}{2} & \multicolumn{2}{|l|}{$\begin{array}{ll}\text { Characters } \\
\end{array}$} \\
\hline & $\begin{array}{l}\text { Bentuk buah lokal Bali dan senjata mainan } \\
\text { sudah sesuai }\end{array}$ & \\
\hline & Pemilihan icon menu sudah tepat & \\
\hline & Pemilihan ukuran icon menu sudah tepat & \\
\hline & $\begin{array}{l}\text { Pewarnaan buah lokal Bali dan senjata } \\
\text { mainan sudah sesuai. }\end{array}$ & \\
\hline 3 & \multicolumn{2}{|l|}{$\begin{array}{rr}\text { Audio } \\
\end{array}$} \\
\hline \multirow{3}{*}{$\checkmark$} & $\begin{array}{l}\text { Penggunaan bahasa yang digunakan dalam } \\
\text { narasi sudah jelas }\end{array}$ & \\
\hline & Pemilihan kata yang digunakan sudah tepat & \\
\hline & $\begin{array}{l}\text { Pengaturan volume pada audio sudah } \\
\text { sesuai }\end{array}$ & \\
\hline \multirow[t]{4}{*}{4} & \multicolumn{2}{|c|}{ Interface } \\
\hline & Petunjuk pengguna aplikasi sudah jelas & \\
\hline & Pemilih menu aplikasi mudah digunakan & \\
\hline & Fungsi tombol aplikas sudah sesuai & \\
\hline \multirow{3}{*}{ No } & Tabel 4. Kisi-Kisi Instrumen & n Ahli Isi \\
\hline & \multicolumn{2}{|c|}{ Butir Penilaian } \\
\hline & Positif & Negatif \\
\hline 1 & Experie & \\
\hline
\end{tabular}




\begin{tabular}{|l|l|l|}
\hline \multirow{2}{*}{} & $\begin{array}{l}\text { Game dapat menambah pengalaman dan } \\
\text { wawasan siswa }\end{array}$ & \multicolumn{1}{|c|}{ Goal of Education } \\
\hline 2 & \multicolumn{1}{|c|}{} \\
\hline \multirow{4}{*}{} & Bentuk dari buah lokal Bali sudah sesuai & \\
\cline { 2 - 3 } & Nama dari buah lokal Bali sudah sesuai & \\
\cline { 2 - 3 } & Tujuan dari game sudah jelas \\
\cline { 2 - 3 } & $\begin{array}{l}\text { Nama buah lokal Bali yang disampaikan } \\
\text { sudah jelas }\end{array}$ & \\
\hline 3 & \multicolumn{1}{|c|}{ Learning } \\
\hline \multirow{2}{*}{$\begin{array}{l}\text { Penggunaan kata dan kalimat dalam narasi } \\
\text { sudah tepat }\end{array}$} & \\
\cline { 2 - 3 } & $\begin{array}{l}\text { Mempermudah guru dalam mengenalkan } \\
\text { buah lokal Bali }\end{array}$ & \\
\hline & Game sudah sesuai dengan RPPH & \\
\hline
\end{tabular}

\section{d. Evaluation}

Evaluasi ini bertujuan untuk mengetahui kekurangan dan kelemahan maupun kesalahan (error) dari aplikasi yang dikembangkan, sehingga aplikasi masih bisa diperbaiki untuk mengurangi kesalahan-kesalahan yang terjadi sebelum diimplementasikan ke masyarakat luas. Jenis pengujian yang akan digunakan adalah uji blackbox, uji ahli media, dan uji ahli isi. Adapun angket evaluasi tahap analysis dan design sebagai berikut.

Tabel 5. Evaluasi tahap analysis

\begin{tabular}{|l|l|l|l|}
\hline No & Pernyataan Sesuai & $\begin{array}{l}\text { Tidak } \\
\text { Sesuai }\end{array}$ & \\
\hline 1 & $\begin{array}{l}\text { Permasalahan dan solusi yang } \\
\text { ditemukan }\end{array}$ & $\begin{array}{l}\text { Kebutuhan fungsional dan non } \\
\text { fungsional perangkat lunak yang } \\
\text { dirancang (aplikasi dari solusi) }\end{array}$ & $\begin{array}{l}\text { Tujuan yang terukur pada perangkat } \\
\text { lunak yang dirancang }\end{array}$ \\
\hline 3
\end{tabular}

Tabel 6. Evaluasi Tahap Design

\begin{tabular}{|l|l|l|l|}
\hline No & Pernyataan & Sesuai & $\begin{array}{l}\text { Tidak } \\
\text { Sesuai }\end{array}$ \\
\hline 1 & $\begin{array}{l}\text { Model fungsional perangkat lunak (use case dan activity } \\
\text { diagram) }\end{array}$ & & \\
\hline 2 & Perancangan struktur navigasi perangkat lunak & \\
\hline 3 & $\begin{array}{l}\text { Sekenarion game, atura bermain, keadan menang, dan } \\
\text { keadaan kalah }\end{array}$ & & \\
\hline 4 & Antarmuka game dan 3D objek buah lokal Bali & & \\
\hline 5 & Instrumen uji kebenaran proses (blackbox) & & \\
\hline 6 & $\begin{array}{l}\text { Instrumen uji kelayakan game Balinese Fruit Shooter } \\
\text { sebagai game edukasi pengenalan buah lokal Bali }\end{array}$ & & \\
\hline 7 & Instrumen uji ahli media & & \\
\hline 8 & Instrumen uji ahli isi & \\
\hline
\end{tabular}




\section{HASIL PENELITIAN}

Hasil penelitian yang telah dilakukan adalah aplikasi game Balinese Fruit Shooter berbasis Virtual Reality yang dijalankan pada sistem operasi Windows dengan bantua alat HTC VIVE sebagai controller. Adapun hasil pengembangan aplikasi game Balinese Fruit Shooter berdasarkan model ADDIE sebagai berikut.

\section{A. Hasil Tahap Analysis}

Hasil tahap analysis terhadap pengembanagn game Balinese Fruit Shooter berbasis virtual reality dari kebutuhan fungsional perangkat lunak sebagai berikut.

1. Aplikasi mampu menampilkan main menu (menu utama) sebelum menuju ke permainan. Adapun icon bagian dari main menu, yaitu Mulai, Tentang, Pengaturan, Skor Tertinggi dan Keluar.

2. Aplikasi mampu menampilkan pilihan tempat bermain, yaitu ruang bermain, halaman sekolah, dan hutan.

3. Aplikasi mampu memulai permainan baru dan menampilkan game utama, yaitu menembak buah lokal Bali.

4. Aplikasi mampu menampilkan poin tertinggi pada permainan.

5. Apliaksi mampu menampilkan skor yang telah didapat dari hasil menembak buah lokal Bali.

6. Apliasi mampu mengeluarkan suara nama buah lokal Bali yang telah ditembak oleh pemain.

7. Aplikasi mampu mengatur volume suara dari apliaksi.

8. Aplikasi mampu menampilkan informasi tentang game dan identitas pengembang.

9. Aplikasi mampu menampilkan cara bermain (tutorial)

10. Aplikasi mampu menampilkan perintah keluar dari aplikasi
11. Aplikasi mampu menampilkan nama dari buah lokal Bali ketika membidik buah ketika memulai permainan.

12. Aplikasi mampu menampilkan waktu reload buah lokal Bali

13. Aplikasi mampu menampilkan nyawa yang dimiliki oleh pemain

\section{B. Hasil Tahap Design}

Hasil tahap design terhadap pengembanagn game Balinese Fruit Shooter berbasis virtual sebagai berikut.

1. Hasil Antarmuka Perangkat Lunak

- Hasil Antarmuka Tampilan Awal Lingkungan (kelas)

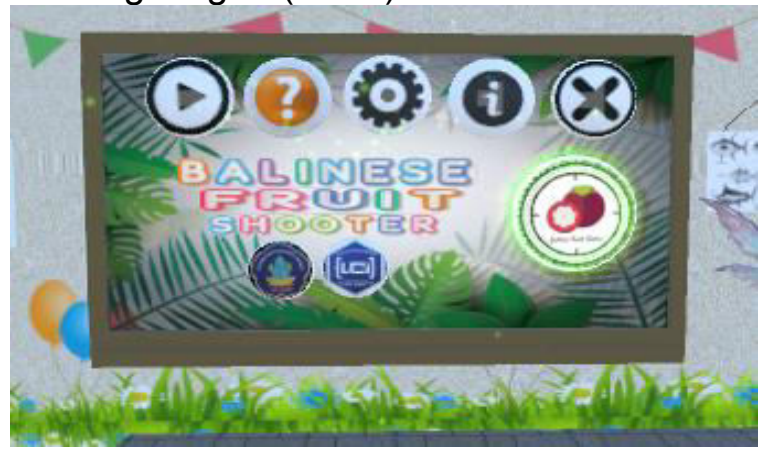

Gambar 11. Hasil Antarmuka Tampilan Awal Lingkungan

- Hasil Antarmuka Tampilan Mulai

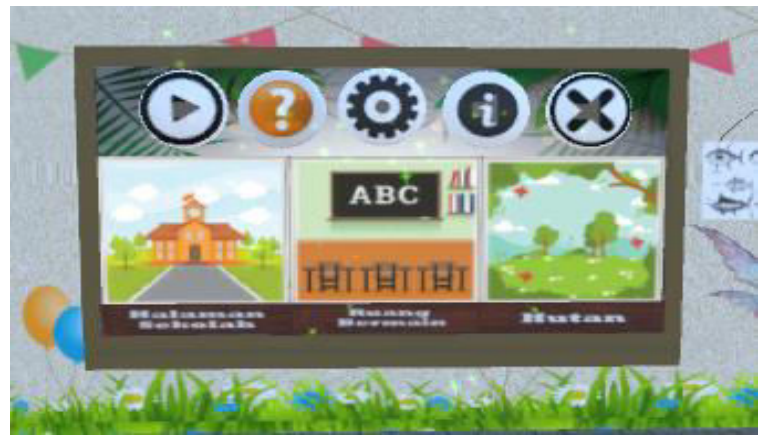

Gambar 12. Hasil Antarmuka Tampilan Mulai

- Hasil Antarmuka Tampilan Ruang Bermain 


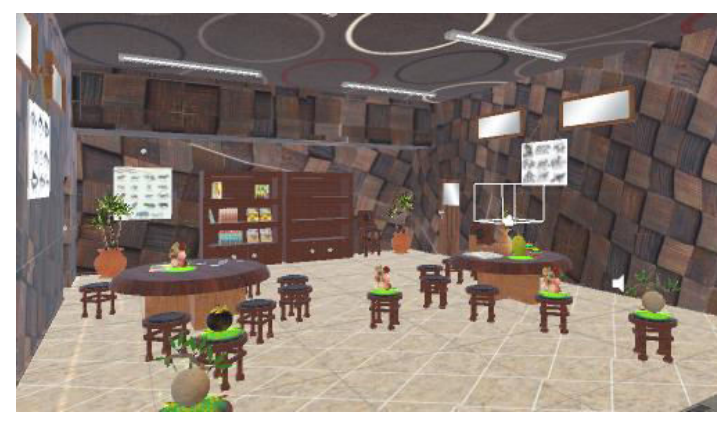

Gambar 13. Hasil Antarmuka Tampilan Ruang Bermain

- Hasil Antarmuka Tampilan Halaman Sekolah

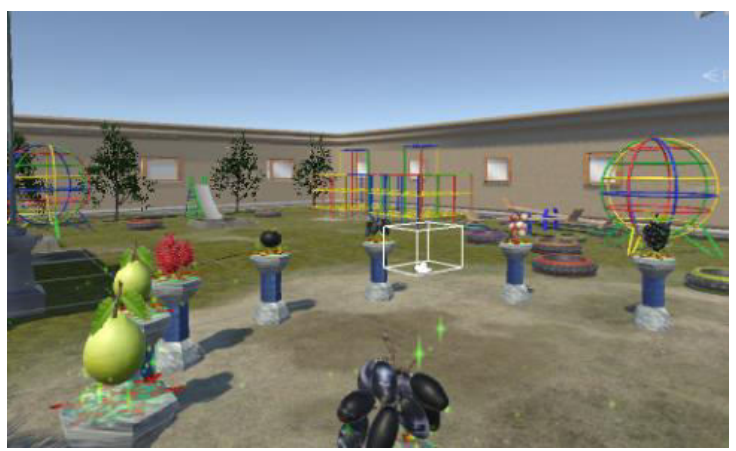

Gambar 14. Hasil Antarmuka Tampilan Halaman Sekolah

- Hasil Antarmuka Tampilan Hutan

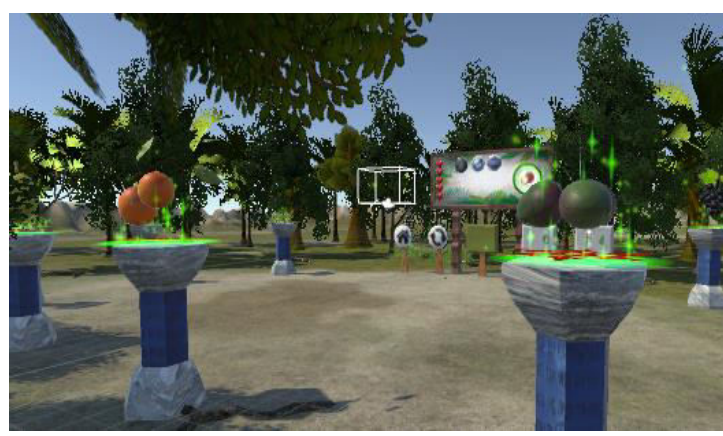

Gambar 15. Hasil Antarmuka Tampilan Hutan

- Hasil Antarmuka Tampilan Cara Bermain

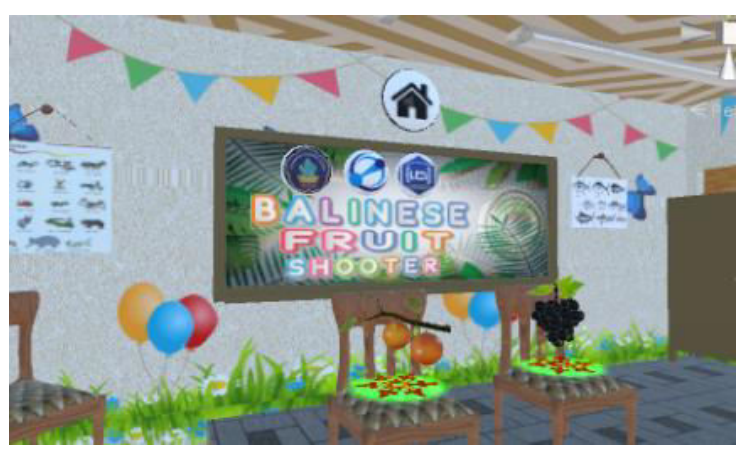

Gambar 16. Hasil Antarmuka Tampilan Cara Bermain

\section{Hasil Implementasi Pengujian}

- Uji Blackbox

Pelaksanaan uji kasus untuk pengujian blackbox dapat dilaksanakan dengan 2 butir kasus uji.

a) Uji Kebenaran Proses

Pada pengujian kasus uji 1 memiliki tujuan untuk menguji kebenaran proses dari game Balinese Fruit Shooter sesuai dengan target yang ingin dicapai. Pada proses pengujian ini setiap mahasiswa yang terdiri dari 5 orang akan diberikan angket setelah mencoba memainkan Balinese Fruit Shooter. Pelaksanaan pengujian kasus uji 1 mendapatkan kriteria sangat sesuai, dengan perolehan nilai $96 \%$

b) Uji Kelayakan Sebagai Game Edukasi Pengenalan Buah Lokal Bali

Pengujian kasus uji 2 dilakukan untuk mengetahui apakah aplikasi yang dibuat layak sebagai game edukasi pengenalan buah lokal Bali. Pada tahap ini setiap orang tua murid yang terdiri dari 5 orang akan diberikan angket pengujian setelah mencoba memainkan game Balinese Fruit Shooter sampai akhir. Pelaksanaan pengujian kasus uji 2 mendapatkan kriteria sangat sesuai, dengan perolehan nilai $95 \%$.

- Uji Ahli Media 
Uji ahli media dilakukan untuk menguji kesesuaian antara rancangan game yang telah ditetapkan dengan hasil pengembangan game. Pengujian ahli media akan diulang kembali apabila masih terdapat revisi dari penguji. Pada uji ahli media, pengujian dilakukan oleh 2 orang ahli media, yaitu I Made Ardwi Pradnyana, S.T.,M.T yang merupakan dosen di jurusan PTI UNDIKSHA dan Nyoman Sugihatini, S.Pd.,M.Pd yang merupakan dosen di jurusan PTI UNDIKSHA. Berdasarkan penilaian dari ahli media Bapak I Made Ardwi Pradnyana, S.T., M.T diperoleh nilai 95\% dan dari Ibu Nyoman Sugihartini, S.Pd.,M.Pd diperoleh nilai $98 \%$. Analisis untuk uji ahli media berada dalam kriteria sangat sesuai, dengan persentase $96,5 \%$.

\section{- Uji Ahli Isi}

Uji ahli isi dilakukan pada bagian sub tema buah-buahan dengan kegiatan inti mengelompokkan buah-buhan sesuai dengan warna melalui video game. Pada uji ahli isi, pengujian dilakukan oleh dua orang sebagai ahli isi, yaitu lbu Luh Kerti, S.Pd merupakan guru TK Ceria Asih Singaraja dan Ibu Ni Gusti Ayu Made Yeni Lestari, M.Pd merupakan dosen di jurusan PG PAUD UNDIKSHA. Berdasarkan penilaian dari ahli isi, yaitu lbu Luh Kerti, S.Pd diperoleh nilai $100 \%$ dan Ibu Ni Gusti Ayu Made Yeni Lestari, M.Pd diperoleh nilai $95 \%$. Analisis untuk uji ahli media berada dalam kriteria sangat sesuai, dengan persentase $97,5 \%$.

\section{Hasil Tahap Evaluation}

\section{Hasil Evaluasi Analysis}

Pada tahap analysis, bagian kebutuhan fungsional ditambahkan, yaitu aplikasi mampu menampilkan nama dari buah lokal Bali ketika membidik buah ketika memulai permainan, aplikasi mampu menampilkan waktu reload buah lokal Bali, aplikasi mampu menampilkan nyawa yang dimiliki oleh pemain. Begitu pula pada tujuan pengembangan perangkat lunak. Pada evaluasi analysis, seluruh komponen yang dibutuhkan pada tahap analysis sudah sesuai dapat dilihat pada Tabel 7 .

Tabel 7. Hasil Evaluasi Analysis

\begin{tabular}{|l|l|l|l|}
\hline No & Pernyataan Sesuai & $\begin{array}{l}\text { Tidak } \\
\text { Sesuai }\end{array}$ \\
\hline 1 & $\begin{array}{l}\text { Permasalahan } \\
\text { dan solusi yang } \\
\text { ditemukan }\end{array}$ & $\sqrt{ }$ & \\
\hline 2 & $\begin{array}{l}\text { Kebutuhan dan } \\
\text { fungsional dangsional } \\
\text { non fun } \\
\text { perangkat lunak } \\
\text { yang dirancang } \\
\text { (aplikasi dari } \\
\text { solusi) yang }\end{array}$ & $\sqrt{ }$ & \\
\hline 3 & $\begin{array}{l}\text { Tujuan yada yan } \\
\text { terukur pada } \\
\text { perangkat lunak } \\
\text { yang dirancang }\end{array}$ & & \\
\hline
\end{tabular}

\section{Hasil Evaluasi Design}

Pada tahap design, bagian antarmuka diubah sedemikian rupa dengan penambahan nyawa pemain dan papan pada bagian mulai permainan. Pada evaluasi design, seluruh komponen yang dibutuhkan pada tahap design sudah sesuai dapat dilihat pada Tabel 8.

Tabel 8. Hasil Evaluasi Design

\begin{tabular}{|c|c|c|c|}
\hline No & Pernyataan & Sesuai & $\begin{array}{l}\text { Tidak } \\
\text { Sesuai }\end{array}$ \\
\hline 1 & $\begin{array}{l}\text { Model fungsional } \\
\text { perangkat lunak } \\
\text { (use case dan } \\
\text { activity diagram) }\end{array}$ & $\sqrt{ }$ & \\
\hline 2 & $\begin{array}{l}\text { Perancangan } \\
\text { struktur navigasi } \\
\text { perangkat lunak }\end{array}$ & $\sqrt{ }$ & \\
\hline 3 & \begin{tabular}{ll}
\multicolumn{2}{l}{ Sekenarion game, } \\
atura & bermain, \\
keadan & menang, \\
dan & keadaan \\
kalah &
\end{tabular} & $\sqrt{ }$ & \\
\hline
\end{tabular}




\begin{tabular}{|l|l|l|l|}
\hline 4 & $\begin{array}{l}\text { Antarmuka game } \\
\text { dan 3D objek } \\
\text { buah lokal Bali }\end{array}$ & $\sqrt{ }$ & \\
\hline 5 & $\begin{array}{l}\text { Instrumen uji } \\
\text { kebenaran proses } \\
\text { (blackbox) }\end{array}$ & $\sqrt{ }$ & \\
\hline 6 & $\begin{array}{l}\text { Instrumen uji } \\
\text { kelayakan game } \\
\text { Balinese Fruit } \\
\text { Shooter sebagai } \\
\text { game edukasi } \\
\text { pengenalan buah } \\
\text { lokal Bali }\end{array}$ & $\sqrt{ }$ & \\
\hline 7 & $\begin{array}{l}\text { Instrumen uji ahli } \\
\text { media }\end{array}$ & $\sqrt{ }$ & \\
\hline 8 & $\begin{array}{l}\text { Instrumen uji ahli } \\
\text { isi }\end{array}$ & $\sqrt{ }$ & \\
\hline
\end{tabular}

\section{Pembahasan}

Perancangan antarmuka game Balinese Fruit Shooter menggunakan berbagai aplikasi, seperti Unity 3D, Blender, Adobe Premiere. Unity 3D digunakan dalam pembuatan game dengan plugin VR-nya adalah Steam VR. Steam VR bertujuan untuk menghubungkan HTC VIVE dengan lingkungan game melalui headset dan controller. Platform yang digunakan dalam game ini adalah Windows, sehingga dalam mengimplementasikan menggunakan komputer, hal ini selaras dengan HTC VIVE yang support terhadap komputer. Kelebihan dalam terhadap platform Windows adalah apa yang dilakukan pemain di dalam lingkungan maya dapat dilihat pada komputer, sehingga orang yang tidak sebagai pemain dapat melihat yang dilakukan oleh pemain. Blender digunakan dalam pembuatan asset lingkungan, karakter, dll. Unntuk memperindah tampilan dari texture, digunakan aplikasi Adobe Photoshop dan dengan perpaduan dari fitur Unity 3D, yaitu material. Sedangkan, untuk pengaturan amplify dari suara game digunakan Adobe Premiere.

Pengujian aplikasi dilakukan untuk mengetahui tingkat kelemahan serta kesalahan (error) dari game yang dikembangkan. Sehingga game masih bisa diperbaiki untuk mengurangi kesalahan-kesalahan yang terjadi sebelum diimplementasikan ke masyarakat luas. Berdasarkan hasil yang diperoleh dapat disimpulkan bahwa game Balinese Fruit Shooter, dapat digunakan untuk pembelajaran dengan sub tema buahbuahan. Hal ini dapat dilihat dari kriteria yang didapat dari hasil pengujian kebenaran proses $96 \%$, pengujian kelayakan sebagai game edukasi pengenalan buah lokal Bali 95\%, pengujian ahli media 96,5\%, dan pengujian ahli isi $97,5 \%$.

\section{SIMPULAN}

Berdasarkan hasil analisis, implementasi dan pengujian pada penelitian pengembangan game Balinese Fruit Shooter berbasis Virtual Reality sebagai media pembelajaran dapat ditarik kesimpulan bahwa implementasi pengembangan game Balinese Fruit Shooter berbasis Virtual Reality sebagai media pembelajaran mendapat hasil yang sangat baik. Berdasarkan hasil yang diperoleh dapat disimpulkan bahwa game Balinese Fruit Shooter, dapat digunakan untuk pembelajaran dengan sub tema buah-buahan di TK. Hal ini dapat dilihat dari kriteria yang didapat dari hasil pengujian kebenaran proses $96 \%$, pengujian kelayakan sebagai game edukasi pengenalan buah lokal Bali 95\%, pengujian ahli media 96,5\%, dan pengujian ahli isi $97,5 \%$.

\section{SARAN}

Berdasarkan hasil penelitian pengembangan dan kesimpulan, dapat disarankan bagi pembaca yang ingin mengembangkan aplikasi ini sebagai berikut.

1. Anak-anak yang ingin bermain game Balinese Fruit Shooter, harus didampingi oleh orang tua, 
dikarenakan penggunaan alat HTC VIVE yang menyarankan ketika anakanak bermain harus berada pada pengawasan orang tua

2. Pembuatan game selanjutnya dapat dikembangkan dengan menonjolkan edukasi, penambahan buah lokal Bali dan menambahkan level terhadap game, namun harus sesuai dengan kegiatan pada $\mathrm{RPH}$, yaitu mengelompokkan buah lokal bali. Selain itu, kegiatan pada RPH seperti, mewarnai gambar buah buahan, membuat coretan pada gambar berbentuk huruf, dan menebalkan tulisan buah buahan dapat ditambahkan pada game.

\section{REFERENSI}

[1] Rai, N. (2016). Buah-Buahan Lokal Bali: Jenis, Pemanfaatan dan Potensi Pengembangannya.

Denpasar: Percetakan Pelawa Sari.

[2] Hikmah, N. (2014). Distribusi Buah Lokal Dan Buah Import (Studi Kasus Pada Pedagang Buah Di Kota Semarang). Jurnal UNTAG Semarang. 3(1): 2302-2752.

[3] Al-Maqassary, A. (2013). Pengertian Media Pembelajaran. Retrieved from Jurnal Hasil Riset: (http://www.ejurnal.com/2013/12/pengertian-mediapembelajaran.html)

[4] Herlangga, K. G. (2016, Maret 7). Virtual Reality dan Perkembangannya. Retrieved from Codepolitan: (https://development.codepolitan.com/ virtual-reality-dan-perkembangannya.)

[5] Wati, M. S. (2016). Pengembangan Game Meboros Kidang Sebagai Bentuk Pelestarian Tradisi Meboros di Bali. Karmapati. 5(1): 2252-9063.

[6] Zamroni, R. (2013). Rancangan Bangun Apliaksi Permainan Untuk Pembelajaran Anak Mengunakan HTML 5. Jurnal Teknik. 5(2): 20850859. 